\title{
Service System Interactions At Tertiary Institutions: A South African Perspective
}

Paul Green, Durban University of Technology, South Africa

\begin{abstract}
A university as an institution has a distinct identity and has a meaningful role to play in society. A university in its entirety is a system comprising of many sub-systems. The university's stakeholders represent various systems, viz. students, parents, government, donors, public, etc. It is the interaction of these systems that is critical for the successful measure of service quality.

This paper focusses on three objectives. Firstly, the notion of service and the classification of education as a service are discussed. Secondly, service as a system is discussed, with particular reference to the Work System Framework (WSF) and the application thereof to a university. Thirdly, the Interact-Serve-Propose-Agree-Realize (ISPAR) Model, and application of the ISPAR model to a university, are reported. It is evident from this paper that service is a major factor in tertiary institutions, and specifically in South Africa, service cannot be overlooked.
\end{abstract}

Keywords: Service Systems; Work System Framework; ISPAR Model; South Africa; Tertiary; Service Quality

\section{INTRODUCTION}

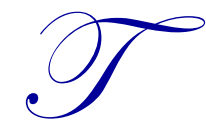

he research presented in this paper is a segment of a research project that sets out to develop a conceptual framework for the evaluation of an academic department as a service provider at a university of technology. The services sector has contributed significantly to the growth and development of world economies and is today one of the largest and fastest growing sectors globally (Okoe, Adjei, \& Osarenkhoe, 2013). Testimony to the rise in the supply of services is the fact that the services sector contributes more to the global output and employs more people than any other sector. It has been widely accepted that education belongs to the category of service industries (Sultan \& Wong, 2012), resulting in the importance of rendering a quality service. In South Africa, although education is the recipient of the major portion of national expenditure (Statistics South Africa, 2007), government funding to tertiary institutions has been on the decline, prompting institutions of higher learning to develop innovative methods to maintain financial stability. One of the strategies has been to attract and retain national and international students by the rendering of a quality service.

\section{WHAT ARE SERVICES?}

According to Spohrer, Maglio, Bailey, and Gruhl (2007, p. 71), service industries, including higher education, over the last two decades have developed to be the largest part of most industrialized economies. Young and Burgess (2010) mention that around $75 \%$ of the economic activity generated in the American economy is represented in the service sector, while $76 \%$ of economic activity in the United Kingdom is found in service industries. In South Africa, the service industry constitutes $67.1 \%$ of the gross domestic product of the country (Boshoff \& du Plessis, 2009). Boshoff and du Plessis (ibid) further suggest there is growing demand for services and the increasing dominance of services in economies across the world is not limited to South Africa. Despite such significant growth of the service economy, there is no widely accepted definition of service (Koni, Zainal \& Ibrahim, 2013). Service productivity, quality, compliance, and innovation all remain hard to measure (Spohrer et al., 2007, p. 8). Table 1 shows the typical definitions of service. 
Table 1: Typical Definitions of Service

"A service is any act or performance that one party can offer to another that is essentially intangible and does not result in the
ownership of anything." (Kotler \& Keller, 2006, p. 402)
"A service is a time-perishable, intangible experience performed for a customer acting in the role of a co-producer."
(Fitzsimmons \& Fitzsimmons, 2010, p. 4)
"Service [is] the application of resources for the benefit of another" (Vargo \& Lusch cited in Spohrer, Vargo, Maglio, \&
Caswell, 2008, p. 1)
"Services are deeds, processes, and performances provided or coproduced by one entity or person for another entity or
person." (Zeithaml, Bitner \& Gremler, 2009, p. 4)

Alter (2008) observes that the definition of services encompasses a wide range of services - for external and internal customers; personal and impersonal; repetitive and non-repetitive; long-term and short-term customized, semi-customized, and non-customized services; automated, IT-reliant, and non-automated services; and those with varying degrees of self-service responsibilities.

Kandampully, Mok and Sparks (2004, p. 6) state that service has been defined as "any activity or benefit one party can offer to another that is essentially intangible and does not result in the ownership of anything." Conversely, goods are defined as "tangible economic products that are capable of being seen and touched and may or may not be tasted, heard or smelled" (Mudie \& Pirrie, 2006, p. 2). In marketing, goods and services are used interchangeably as they are both regarded as products. For the purpose of this paper, it is important to dissect this statement as individuals, who are unfamiliar with this, may regard a "product" as a physical object with identifiable and tangible attributes (Baker, 2003, p. 119). Various services might thus not be considered as products (a lecturer delivering a presentation to a group of Financial Accounting students). Zikmund and D'Amico (2002, p. 30), on the other hand, define a product as "a good, service or idea that offers a bundle of tangible and intangible attributes to satisfy consumers." As a consequence, goods and services may both be regarded as products.

Edgett and Parkinson (1993, p. 19), in a review of the service industry, mention that it is generally accepted that the marketing of services is different from the marketing of physical goods due to their unique characteristics. Services have distinctive characteristics which differentiate them from goods and have implications for the manner in which they are marketed. One of the fundamental distinctions between goods and services is that "goods" are "things" and a "service" is an "act."

Palmer and Cole (1995, p. 24) distinguish between a good and a service on a continuum as shown in Figure 1.

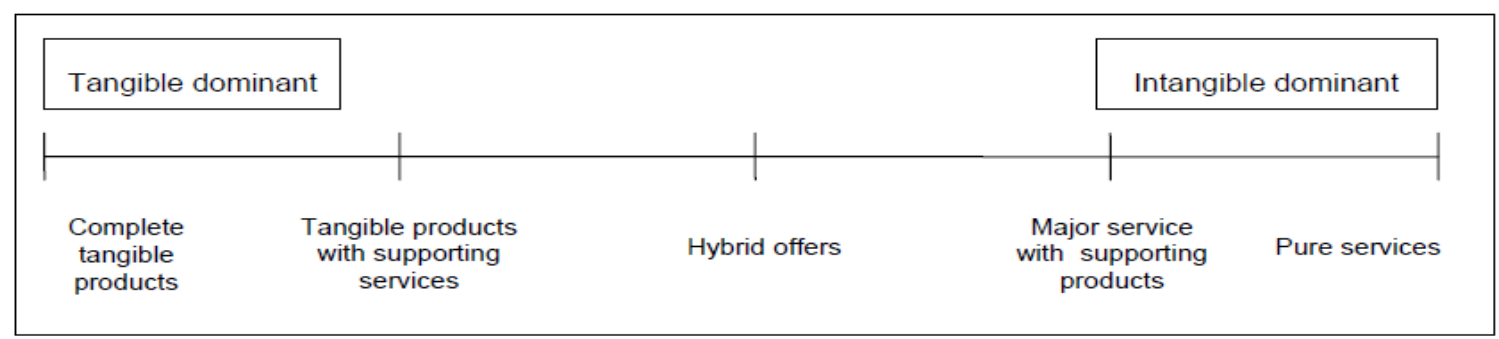

Figure 1: Goods and Services Continuum

Source: Palmer and Cole (1995, p. 24)

At one end of the continuum are the tangible products and at the other end are the intangible services. Higher education has been described as a service (Ivy, 2008, p. 289; Alter, 2008, p. 72) (intangible) with supporting products (tangible), leaning towards the intangible side of the goods and services continuum. Tertiary institutions provide service activities such as the teaching process and contact with customers (intangible element), as well as learning materials such as textbooks (tangible elements). 
Lovelock \& Wright (2002, p. 14) highlight some basic characteristics of services:

- $\quad$ Customers do not obtain ownership. Customers usually derive value from a service without obtaining ownership of any tangible elements.

- $\quad$ There is customer involvement in the production process. Customers are frequently actively involved in creating the service product by helping themselves or by co-operating with the staff rendering the service.

- $\quad$ Time is important. Customers have to be physically present to receive services. Some customers are sensitive to time and often speed is a key element to good service delivery.

- $\quad$ Services are perishable and cannot be stored like physical goods.

Danjuma and Rasli (2012, p. 96) assert that students are considered as customers because as fee payers, they are buying educational services for their satisfaction. A learner would register at a university to obtain a particular qualification. The knowledge gained while registered at a university is dependent upon a learner's ability to glean information from the educator. If this process is successful, then the learner derives value from the service arguably without obtaining any tangible elements besides a certificate at the successful completion of a course. Educational literature reassures education appraisers that in order for effective learning to occur, learning needs to be active. At a university, it is expected of students to co-operate in the learning process; i.e., with submission of assignments, presentations, self-study, etc. At a university, time is an important factor as a university is largely a bureaucratic organisation controlled by time. A learner needs to be physically present to receive most services. However, it has become a common practice to exercise non-contact learning via the use of social networks, on-line learning, DVD's, etc. Unlike physical goods, services at a university are perishable and cannot be stored; yesterday's course opening cannot be sold. A learner is expected to be present when a particular topic is discussed as information is dynamic and constantly changing. Production and consumption must take place simultaneously. Based on the characteristics of services highlighted above and their relation to a university, one can deduce that a university belongs to the category of educational services.

Several authors, including Boshoff and du Plessis (2009, p. 248), Zeithaml et al. (2009, p. 20), and Kotler and Armstrong (2010), suggest that services have the unique characteristics of intangibility, inseparability, heterogeneity and perishability. Because education may be classified as a service (Zeithaml, Bitner \& Gremler, 2009), these unique characteristics are also applicable to education.

\section{EDUCATION AS A SERVICE}

Du Toit (2004, p. 183) concludes that education is a service directly impacted on by the provider and it is only as effective or inadequate as the quality of both the academic and non-academic services. Higher education institutions are increasingly placing greater emphasis on meeting students' expectations and needs. Education, as a service, is committed to satisfying the educational needs of its clients by creating educational services required by learners and not constraining them to accept existing educational facilities. Diversified educational provision does not guarantee a high quality of education, but different educational services are in a constant state of competition. Vargo and Lusch $(2004$, p. 2) define services as the application of specialized competencies (knowledge and skills) through deeds, processes, and performances for the benefit of another entity or the entity itself. This implies that almost any purposeful system within a business or governmental entity, including higher education institutions, can be viewed as a service system, as competencies are being applied to something for someone.

Badat (2009, p. 5) identifies three key purposes of universities, specifically in a South African context. Firstly, a university is meant to produce knowledge which advances understanding of the natural and social worlds and enriches humanity's accumulated scientific and cultural inheritances and heritage. Secondly, a university is for the dissemination of knowledge and the formation and cultivation of the cognitive character of students. Thirdly, which he admits is somewhat newer but increasingly accepted, is that a university must undertake community engagement. It is against this background and for the purpose of this paper that a university, which is in close association with its stakeholders and sensitive to the economic and social conditions, needs to be explored as a service organisation. A university and society need to be linked whereby the needs of society need to be at the core of universities' activities. Klose and Finkle (1995, p. 638) mention that one of the major causes of poor performance by service organisations is not knowing what customers expect. Service organisations are eager to 
provide good service, but fall short as they do not understand exactly what customers expect from the service (Palmer and Cole, 1995, p. 513). Further support is obtained from Shahin (2005, p. 1) who states that it is essential for service organisations to understand and measure customer expectations and perceptions from their customers' perspective in order to identify gaps in the service quality.

\section{SERVICE AS A SYSTEM}

Vargo and Lusch (2004, p. 10) define a service system as a dynamic value co-creation configuration of resources, including people, organizations, shared information and technology all connected internally and externally to other service systems by value propositions. They suggest that the most fundamental dichotomy related to resources is that of operant and operand resources. Operant resources use operand resources to create value - realize some benefit for others and a future version of the operant resource (Spohrer, Anderson, Pass, \& Ager, 2008, p. 3). For example, a lecturer (operant resource) may use an interactive teaching tool (operand resource) to realize the value of a more interactive lecture. A service system is a configuration of resources, so it is also a resource itself. Anderson, Narus, and van Rossum (2006, p. 4) describe the requirements of successful value propositions. The design of a successful value proposition requires knowledge of the capabilities and needs of the provider, customers, and competitors.

In another definition, Maglio et al. (2009, p. 33) define a service system as an open system capable of improving the state of another system through sharing or applying its resources (the other system determines and agrees that the interaction has value) and capable of improving its own state by acquiring external resources (the system itself sees value in its interaction with other systems). Maglio et al. (2009) observe service systems as dynamic - composing, recomposing, and decomposing over time. Service systems that continue, to a large extent, in the same form over long periods are open systems through which operand resources flow, but in which operant resources are stable.

Following is a discussion and application of two service systems selected for this paper.

\subsection{The Work System Framework (WSF)}

According to Alter (2008, p. 72), service systems produce all services of significance and scope, yet the concept of a service system is not well articulated in the service literature. Alter (2007, p. 34) argues that a service system is a useful fundamental unit for understanding, analyzing, and designing services. Alter (2007, p. 35) proposes a work system framework for service organizations (which is an extension of his original ideas to service organizations) which is applicable to a wide range of services. The WSF provides a rich and broadly applicable model of how services operate and evolve. It creates a platform for comparing service situations, identifying important special cases of services, and describes service-design strategies.

The work system framework consists of nine elements of which four are internal and five are external. The first four elements are the basic components that actually perform the work; these include participants, information, processes \& activities, and technologies. The five external elements include strategies used by the work system and the organization, infrastructure shared with other work systems, environmental factors that surround the work system, products and services the work system produces, and customers for those products and services. The arrows within the framework indicate that the various elements of a work system should be in balance (Figure 2). 


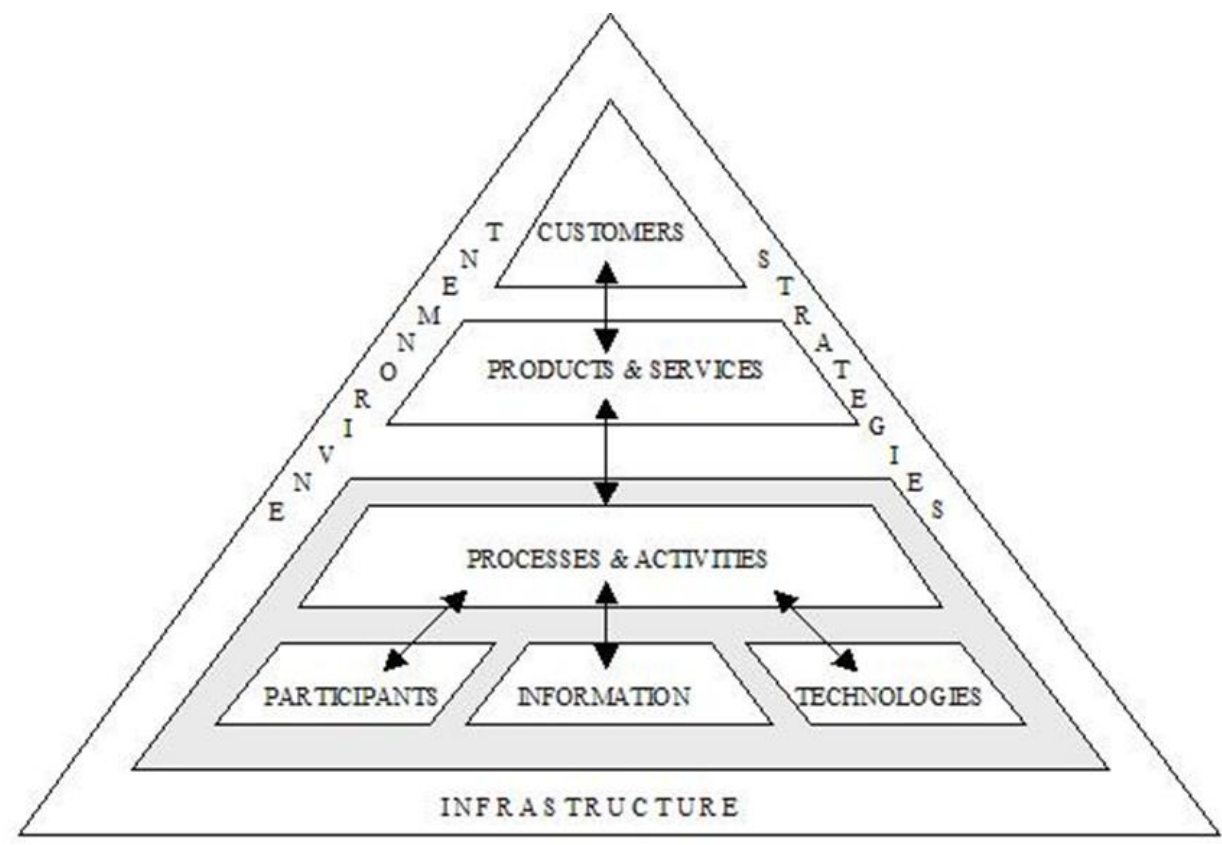

Figure 2: The Work System Framework (Adapted From Alter, 2006, p. 13)

\subsubsection{Application of the Work System Framework in Relation to a University}

Alter (2006, p. 14) describes customers as people who receive, use or derive direct benefit from products and services that a work system produces. Customers include both internal and external customers. External customers receive and use the economic products and/or services that an organization produces while internal customers are employees or contractors who receive and use a work system's products and/or services while performing work. At a university, the customers would include students, staff, parents, donors, government, management and employers.

Products and services are the combination of physical elements, information and services that the work system produces for its various customers (Alter, 2006, p. 14). In the case of a university, the products and services would include tuition, administrative services, and auxiliary services such as counselling, health care, library, financial assistance, accommodation and catering. In addition, there are social products, such as student societies, organizations, sport and cultural activities.

Activities and processes entail all the work practices within the work system. Alter (2006, p. 15) suggests that these activities may combine information processing, communication, decision-making, coordination, thinking, and physical actions. The major activities and processes undertaken at a university would include teaching and learning, which includes lectures, tutorials and assessments.

The participants are people who perform the work. At a university, the work will be performed by two tiers of staff, viz. academic and administrative staff. The academic staff will provide the main activity of teaching while the administrative staff will render institutional support.

Information includes codified and non-codified information used and created as participants perform their work. Technologies are the tools that help people work more efficiently. At a university, the information is vast from student records to information kept by academic and administrative staff. Technologies would involve computers, software packages, banking facilities, etc.

Alter (2006, p. 15) mentions that environment includes the organizational, cultural, competitive, technical, and regulatory environment within which the work system operates. Factors in the environment will affect system 
performance, even though the system does not rely directly on them in order to operate. Common environmental elements in most South African universities over the past decade have been student unrest and political violence. Government regulations would also impact on the work system as institutions of higher learning report to councils which have been put in place by the Higher Education Act. Another important factor worth noting in this study is the merger of two tertiary institutions with diverse backgrounds having different ideologies.

Infrastructure in the work system method would include human, information and technical resources even though these resources are managed outside of the system and shared with other work systems. At a university, this would include the lecture venues, libraries, computer laboratories, etc.

Alter (2006, p. 16) refers to strategies as the guiding rationale and high-level choices within which a work system operates. This would normally entail the vision and mission of a university. Following the third objective of this paper is a discussion and application of the ISPAR model to a university environment.

\subsection{The Interact-Serve-Propose-Agree-Realize (ISPAR) Model}

Not all service system interactions qualify as service. The Interact-Serve-Propose-Agree-Realize (ISPAR) model proposed by Spohrer, Vargo, Maglio, and Caswell (2008, p. 7) attempts to explain the possible outcomes between service systems. The ISPAR is a normative model that aims to cover the space of ten possible interactions between two interactive service systems. The ISPAR model of service systems is characterized by interaction episodes. An interaction episode is described as a series of activities jointly undertaken by two service systems. The interactions can be service, which are interactions that aim to co-create value, or non-service interactions.

An interaction is said to be a service interaction if a proposal is made by one party to another, agreement is reached between the parties, and value is realized by both. If value is not realized, it may result in a dispute which, in turn, may or may not be resolved to the satisfaction of both parties. If an interaction is not a service interaction, it may be welcome or unwelcome, and some unwelcome interactions may be illegal (Maglio et al., 2009).

Figure 3 is an explanation of the application of the ISPAR model:

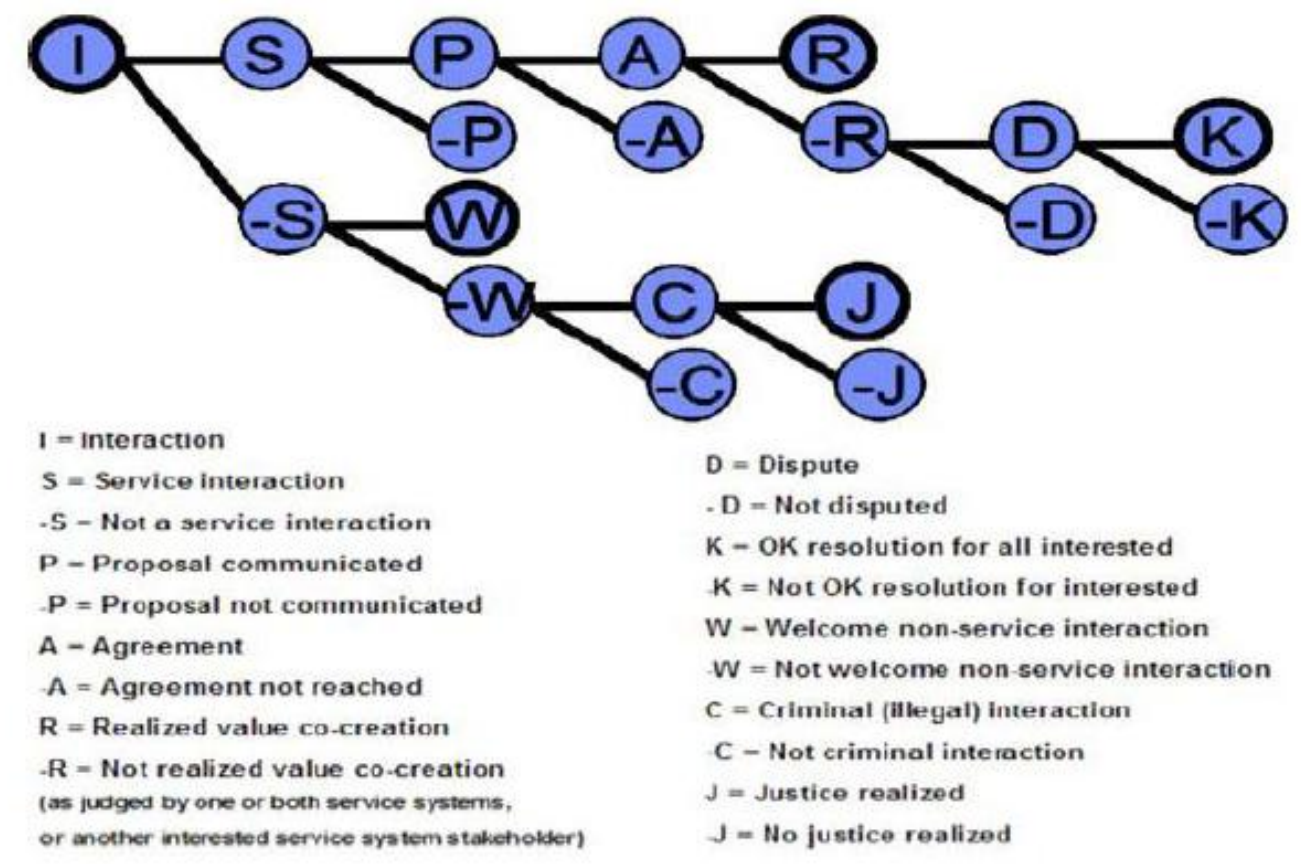

Figure 3: The ISPAR Model of Service System Interactions Source: Spohrer, Vargo, Maglio \& Caswell (2008) 
1. Outcome (R): This outcome is the realization of the proposed and agreed to value proposition. This is a desired outcome and the value realization outcome $(\mathrm{R})$ corresponds to a win-win interaction. In this outcome, the service interaction is successful, value is co-created, and both service systems realize the benefit from the service interaction.

2. Outcomes (-P) and (-A): In this outcome, a proposal may not be successfully communicated or comprehended by the other service system (-P) and may lead to the interaction being terminated. Or a proposal may be communicated, but activities between the service systems may not lead to an agreement $(-\mathrm{A})$, resulting in the service interaction being aborted.

3. Outcomes (-D), (-K), and (K): The value of a proposed service interaction may not be realized, and it is possible that no dispute (-D) arises. When a dispute arises, the outcome can either be a successful resolution that is acceptable to all the stakeholders $(\mathrm{K})$ or a resolution that is not acceptable to all the stakeholders (-K).

4. Outcome (W): Several interactions between service systems are not service related; however, the interaction may be welcomed (W) by both service systems.

5. Outcomes (-C), $(-\mathrm{J})$, and $(\mathrm{J})$ : When the interaction between service systems is not welcome by one or both service systems, a judgement must be made as to the severity of the unwelcome (-W) non-service interaction, which could lead to a criminal (-C) act. If the criminal is caught and punished, there is no justice (-J) if the criminal cannot be caught and escapes prosecution. If it is a criminal activity, a series of activities undertaken by several service systems interacting can result in justice $(\mathrm{J})$.

The ISPAR model enables one to see the world as populations of interacting service systems of different types - people, businesses, government agencies, etc. (Maglio et al., 2009). An array of entities can by fused by a single abstraction and a great number of measurements can be established. In light of the above-mentioned, it is evident that the ISPAR model could also be applied in a higher education environment.

\subsubsection{Application of the Interact-Serve-Propose-Agree-Realize Model to a University}

Education can be regarded as an open system where lecturers (operant resources) employ resources to deliver quality education. The student has to participate in creating value and so is also an operant using resources (including the lecturer resources, which are now the operand). Teaching and learning by its very nature involves an interaction. This interaction can be between the lecturer and the learner, lecturer and a group of learners or peer group interaction. The desired outcome at the end of a lecture is largely to produce a win-win interaction whereby value is co-created. The author believes that in so doing, a lecturer is attempting to produce life-long learners. This interaction between a lecturer and a learner is coined as a service interaction, according to Spohrer and Maglio (2009). However, there are circumstances in a learning environment when a proposal or concept may not be successfully communicated or comprehended by the learner. The possible reasons for the breakdown in communication or misunderstanding may be attributed to inter alia, learning disabilities, socio-economic factors, culture, language, etc., resulting in an agreement not being reached and, consequently, the non-realization of a value co-creation.

A similar case can be experienced in the administration ambit of a university where the housing department is a system and the student body of the same university is a separate system. A certain number of students enrol at a university with the expectation of receiving housing accommodations from the university. In order for value to be co-created, the university would want to provide suitable accommodations for needy and deserving students and, in return, qualifying students have some expectation of suitable accommodations. In recent years at various universities in South Africa, there have been numerous disagreements between the management of universities and student organisations around the topical issue of student accommodations. Often, this has resulted in activities between the service systems not leading to an agreement and resulting in the service interaction being aborted. Unfortunately, South African tertiary institutions have witnessed some violent service interaction terminations.

The ISPAR model makes provision for outcomes which may be considered as unwelcome non-service interactions. A typical example at a university would be when students engage in unlawful acts and damage university property and threaten the safety of staff and other students. The universities approach the judicial systems of the country and request court interdicts to prevent such behaviour from recurring. If the perpetrators can be 
identified and criminal charges laid, the ISPAR model refers to this as "Justice Realized." However, there have been cases when university property has been damaged and staff vehicles targeted but no culprits have been charged, consequently leaving one or both service systems feeling "No Justice is Realized."

\section{CONCLUSION}

This paper discussed the notion of service, as well as the classification of education as a service, was highlighted. The importance of service organisations in economies, and specifically the importance of service quality in tertiary institutions, were showcased. The fact that there is a reduction in funding allocated to tertiary institutions from national government in South Africa necessitates an urgent intervention of feasible strategies. It is evident from information documented in this paper that tertiary institutions do not operate in silos, but are systems interacting with many other sub-systems. The first service system discussed in this paper was the Work System Framework which illustrates how one could apply this pragmatic model to an institution of higher learning. At a micro and macro level, the ISPAR model - which was the second service system - is suitable in identifying service system interactions and provides a comprehensive overview of the possible interaction sequences between two service systems. However, a criticism of the ISPAR model is its lack of clarity and structure which makes it difficult to analyse service processes. This paper creates a platform for future research to be conducted by applying the two service systems model to a different context, followed by a comparison of the results to the findings of this study.

\section{ACKNOWLEDGEMENTS}

This work is based on the research supported, in part, by the National Research Foundation of South Africa Unique Grant No. 86437.

\section{AUTHOR INFORMATION}

Paul Green is a lecturer at the Durban University of Technology, South Africa. He is a $\mathrm{PhD}$ candidate and his research interests include Systems Thinking, Evaluation, Service Quality and Universities of Technology. E-mail: paulg@dut.ac.za

\section{REFERENCES}

1. Alter, S. (2006). The work system method: Connecting people, processes, and IT for business results. Larkspur, CA: Work System Press.

2. Alter, S. (2007). Could the work system Method embrace systems' concepts more fully? Information Resource Management Journal, 20(2), 33-43.

3. Alter, S. (2008). Service system fundamentals: Work system, value chain, and life cycle. IBM Systems Journal, 47(1), 71-85.

4. Anderson, J. C., Narus, J. A., \& van Rossum, W. (2006). Customer value propositions in business markets. Harvard Business Review, March 2006, 1-9.

5. Badat, S. (2009). The role of higher education in society: Valuing higher education. Paper presented at HERS-SA Academy 2009. University of Cape Town, Graduate School of Business, Cape Town, 14 September 2009.

6. $\quad$ Baker, M. J. (2003). The Marketing Book (5 $5^{\text {th }}$ ed.). Oxford: Butterworth-Heinemann.

7. Boshoff, C., \& Du Plessis, F. (2009) Services marketing: A contemporary approach. Cape Town: Juta.

8. Danjuma, I., \& Rasli, A. (2012). Service quality, satisfaction and attachment in higher education institutions: A theory of planned behaviour perspective. International Journal of Academic Research, 4(2), 96-103.

9. du Toit, A. (2004). How satisfied are our students? Proceedings of the 1st International Conference on Teaching and Learning in Higher Education. Centre for the Development of Teaching and Learning, National University of Singapore. Singapore, pp 182-187.

10. Edgett, S., \& Parkinson, S. (1993). Marketing for service industries - A review. The Service Industries Journal, 13(3), 19-39. 
11. Fitzsimmons, J. A., \& Fitzsimmons, M. J. (2010) Service management (7th ed.). New York: McGraw-Hill.

12. Ivy, J. (2008). A new higher education marketing mix: The 7Ps for MBA marketing. International Journal of Educational Management, 22(4), 288-299.

13. Kandampully, J., Mok, C., \& Sparks, B. (2004). Service quality management in hospitality, tourism and leisure. New York: Haworth Hospitality Press.

14. Klose, A., \& Finkle, T. (1995). Service Quality and the congruency of employee perceptions and customer expectations: The case of an electric utility. Psychology and Marketing, 12, 637-646.

15. Koni, A., Zainal, K., \& Ibrahim, M. (2013). An assessment of the services quality of Palestine Higher Education. International Education Studies, 6(2), 33-48.

16. Kotler, P., \& Armstrong, G. (2010). Principles of marketing (13 ${ }^{\text {th }}$ ed.). [Online] Retrieved 2013, February 13 from http://www.getbookee.org/principles-of-marketing-kotler-13th/

17. Kotler, P., \& Keller, K. L. (2006). Marketing management (12 ${ }^{\text {th }}$ ed.). Upper Saddle River, NJ: Prentice Hall.

18. Lovelock, C., \& Wright, L. (2002). Principles of service marketing and management (2 ${ }^{\text {nd }}$ ed.). Upper Saddle River, NJ: Prentice Hall.

19. Maglio, P. P., Vargo, S. L., Caswell, N., \& Spohrer, J. (2009). The service system is the basic abstraction of service science. Information Systems and E-Business Management, 7(4), 395-406.

20. Mudie, P., \& Pirrie, A. (2006). Services marketing management ( ${ }^{\text {rd }}$ ed.). Oxford: Elsevier.

21. Okoe, A. F., Adjei, J. S., \& Osarenkhoe, A. (2013). Service quality in the banking sector in Ghana. International Journal of Marketing Studies, 5(2), 81-92.

22. Palmer, A., \& Cole, C. (1995). Services marketing: Principles and practice. Englewood, Cliffs, New Jersey: Prentice-Hall.

23. Shahin, A. (2005) SERVQUAL and model of service quality gaps: A framework for determining and prioritizing critical factors in delivering quality services. [Online] Retrieved 2013, July 09 from http://www.proserv.un/docs/Servqual.:1-10

24. Spohrer, J., Anderson, L., Pass, N., \& Ager, T. (2008). Service science and service-dominant logic. Otago Forum 2 (2008). Academic Papers. pp 4-18.

25. Spohrer, J., Maglio, P. P., Bailey, J., \& Gruhl, D. (2007). Steps toward a science of service systems. Computer, 40(1), 71-77.

26. Spohrer, J., Vargo, S., Maglio, P. M., \& Caswell, N. (2008, 7-10 January). The service system is the basic abstraction of service science. Paper presented at the Hawaiian International Conference on Systems Sciences HICSS Conference.

27. Statistics South Africa (2007). Community Survey 2007. Statistical Release P0301. Statistics South Africa, Pretoria.

28. Sultan, P., \& Wong, H. Y. (2012). Service quality in a higher education context: An integrated model. Asia Pacific Journal of Marketing and Logistics, 24(5), 755-784.

29. Vargo, S. L., \& Lusch, R. F. (2004). Evolving to a new dominant logic for marketing. Journal of Marketing, 68(1), 1-17.

30. Young, L., \& Burgess, B. (2010). Marketing technology as a service: Proven techniques that add value. England: John Wiley \& Sons.

31. Zeithaml, V. A., Bitner, M. J., \& Gremler, D. D. (2009). Services marketing: Integrating customer focus across the firm ( $5^{\text {th }}$ ed.). USA: McGraw-Hill/Irwin.

32. Zikmund, W., \& D'Amico, M. (2002). The power of effective marketing: creating and keeping customers in an e-commerce world ( $3^{\text {rd }}$ ed.). Ohio, United States of America: South Western, Thomson Learning. 


\section{NOTES}

